even in healthy infants, ${ }^{5}$ unmasks the true nature of the underlying disorder in many such infants who, already profoundly salt-depleted and unable to tolerate further fluid loss, sink rapidly into severe dehydration and shock. The aldosterone content of breast milk is unknown, but it may, as in the case of progesterone, reflect blood concentration. ${ }^{6}$ The possibility that this or other breast milk steroids might exert a therapeutic effect on breast-fed infants with SL-CAH cannot be excluded, but given the profound salt wasting present in these infants, the plasma concentration of such hormones after absorption from the gastrointestinal tract would seem to be insufficient to influence renal sodium conservation. diagnosis of failure to thrive at the breast, and plasma electrolytes determined before the introduction of formula which may precipitate vomiting. For this reason, although breast feeding should always be encouraged, it is particularly desirable in babies with suspected SL-CAH while the results of confirmatory diagnostic tests are awaited and treatment is begun.

We thank Dr M M Wood, HSC, for statistical analysis, and Miss C Conway for typing the manuscript.
SL-CAH should be included in the differential

hydroxyprogesterone was developed at HSC by $\mathrm{Dr}$ Graham Ellis, using an antibody (type $M$ 156) which was obtained from Professor W R Butt, Birmingham and Midland Hospital for Women.

\section{References}

1 Bongiovanni A M, Root A W. The adrenogenital syndrome. $N$ Engl J Med 1963; 268: 1283-9.

2 Zurbrugg R P. Congenital adrenal hyperplasia. In: Gardner L I, ed. Endocrine and genetic diseases of childhood and adolescence, second edition. Philadelphia: Saunders, 1975: 476-500.

3 Kowarski A A. Mechanism of salt loss in congenital virilizing adrenal hyperplasia. In: Lee $\mathbf{P}$ A, Plotnick L P, Kowarski A A, Migeon C J, eds. Congenital adrenal hyperplasia. Baltimore: University Park Press, 1977: 113-24.

4 Kowarski A, Finkelstein J W, Spaulding J S, Holman G H, Migeon C J. Aldosterone secretion rate in congenital adrenal hyperplasia. A discussion of the theories on the pathogenesis of the salt-losing form of the syndrome. $J$ Clin Invest 1965; 44: 1505-13.

5 Cussen V G H. Breast feeding and neonatal morbidity. In: Wharton B A, ed. Topics in perinatal medicine. Tunbridge Wells: Pitman Medical, 1980: 79-87.

6 Darling J A B, Laing A H, Harkness R A. A survey of the steroids in cows' milk. J Endocrinol 1974; 62: 291-7.

Correspondence to Dr A Curtis, Department of Paediatrics, The Regional Hospital, Wilton, Cork, Ireland.

The radioimmunoassay method for plasma 17- Received 1 September 1982

\title{
Supplementary water for breast-fed babies in a hot and dry climate--not really a necessity
}

\section{N M GOLDBERG AND E ADAMS}

Department of Paediatrics, Joseftal Medical Centre, Eilat, Israel

SUMMARY Urine osmolarity under hot and dry climatic conditions remains within the expected physiological ranges and thus shows that supplementary water for breast-fed infants is not necessary.

It is generally agreed that infants in a hot and dry climate need extra water. This assumption was based more on caution than on knowledge. ${ }^{1}$ Recently breast-fed infants in a hot and humid climate were found to do well without supplementary water. ${ }^{2} 3$

A field study was undertaken in two bedouin villages on the coastal side of the Sinai desert during the summer to find out the fluid requirement of totally breast-fed infants in a hot and dry climate.

\section{Materials and methods}

Fifteen healthy exclusively breast-fed infants ( 9 boys, 6 girls) were studied. They were aged between 40 and 150 days.

Urine was collected using adhesive collector bags. The samples were taken either after 1000 hours or before 1600 hours. Urine was then frozen and analysed within 24 hours using the Fiske osmometer (Fiske Associates, Burlington, Mass. 01803).

Temperature and humidity readings for the duration of the study were provided by the Israeli Meteorological Service.

\section{Results}

Urine osmolarity measurements are shown in the 
Table. Osmolarity ranged between 55 and $320 \mathrm{mmol} / \mathrm{kg}$, with a mean of $164.5 \mathrm{mmol} / \mathrm{kg}$.

The temperature during the study varied between 32 and $37^{\circ} \mathrm{C}$, with a mean temperature of $32.9^{\circ} \mathrm{C}$. Humidity varied between 13 and $41 \%$, with a mean of $26 \cdot 7 \%$.

\section{Discussion}

A newborn baby can concentrate his urine to $700 \mathrm{mmol} / \mathrm{kg}$. By age 3 months he is expected to reach the adult osmolarity $(1200 \mathrm{mmol} / \mathrm{kg}) .{ }^{4}$ It was

calculated that a 4-month-old, totally breast-fed model infant, who weighed $6.3 \mathrm{~kg}$ would have a urinary osmolarity of $216 \mathrm{mmol} / \mathrm{kg}^{2}$. Theoretically, he should manage well in hot climates without additional water. ${ }^{2}$ Most of the infants in our study had a urine osmolarity which was less than $216 \mathrm{mmol} / \mathrm{l}$. All of them had a urine osmolarity considerably less than the maximum which the kidney can produce.

In dry climates water loss is high. This would explain the assumption that breast-fed infants in a hot and dry climate should receive supplementary water.

\section{References}

1 McLaren D S, Burman D. Textbook of paediatric nutrition. Edinburgh: Churchill Livingstone, 1976: 207.

2 Almroth S G. Water requirements of breast-fed infants in a hot climate. Am J Clin Nutr 1978; 31: 1154-7.

3 Armelini P A, Gonzalez C F. Breast feeding and fluid intake in a hot climate. Clin Pediatr (Phila) 1979; 18: 424-5.

4 Vaughan V C, McKay R J, Jr, Behrman R E. Nelson textbook of pediatrics, eleventh edition. Philadelphia: Saunders, 1979: 1479.

Correspondence to Dr Nahum M Goldberg, Department of Paediatrics, Joseftal Medical Centre, Eilat, Israel.

Received 1 March 1982 